\title{
Understanding dentists' management of deep carious lesions in permanent teeth: a systematic review and meta-analysis
}

\author{
Falk Schwendicke* and Gerd Göstemeyer
}

\begin{abstract}
Background: Increasing evidence supports selective/incomplete (SE) or stepwise (SW) instead of non-selective/ complete tissue removal for deep carious lesions in vital teeth, mainly as pulpal risks are significantly reduced. Our aims were to analyze the proportion of dentists who utilize SE/SW for deep lesions in permanent teeth and to identify barriers and facilitators of utilizing SE/SW.

Methods: We included studies that were original, and reported on the proportion of dentists utilizing SE/SW (quantitative studies), or reported on barriers or facilitators of such utilization (qualitative studies). Electronic databases (PubMed, CENTRAL, Embase, PsycINFO) were searched and screening and data extraction performed by two reviewers. Random-effects meta-analysis and meta-regression were used for quantitative synthesis of the proportion of dentists utilizing SE/SW. Thematic analysis was performed to assess barriers and facilitators on SE/SW utilization. Identified themes were translated into the constructs of the theoretical domains framework.

Results: From 1728 articles, nine studies were included, all using quantitative methods. Four thousand one hundred ninety-nine dentists had been surveyed. The mean (95\% Cl) proportion of dentists using SE/SW for deep lesions was $53 \%$ (44/62 \%). More recent studies reported significantly higher proportions $(p<0.05)$. Reported estimates and thematic analysis found dentists' age and an understanding of the disease caries and the scientific rationale behind different removal strategies to affect dentists' behavior. Guidelines, peers, and the social and professional identity were further associated with the motivation of utilizing SE/SW. Environmental incentives, sanctions, or restrictions, mainly of financial but also regulatory character, impacted on decision-making, as did the specific indication (the patient, the tooth) and the beliefs on how well different treatments perform.
\end{abstract}

Conclusions: Around half of all dentists rejected evidence-based carious tissue removal strategies. A range of factors can be addressed for improving implementation. Future studies should use mixed qualitative-quantitative methods to yield a deeper understanding of dentists' decision-making.

Trial registration: PROSPERO CRD42016038047

Keywords: Attitudes, Dental, Decision-making, Evidence-based practice, Qualitative studies, Surveys

\footnotetext{
* Correspondence: falk.schwendicke@charite.de

Department for Operative and Preventive Dentistry, Charité Centre for Dental

Medicine, Aßmannshauser Str 4-6, 14197 Berlin, Germany
} 


\section{Introduction}

Dental caries is a widely prevalent disease, burdening billions of individuals and causing significant healthcare costs $[1,2]$. The treatment of deep carious lesions is especially challenging for dentists, as such lesions are cavitated, with some dentin removal being required prior to placing a restoration to ensure the longevity of the restoration [3], while such removal of dentin in proximity to the pulp is risky [4]. Increasing evidence supports selective ("incomplete") or stepwise instead of nonselective ("complete") dentin removal in deep lesions of permanent teeth, as both avoid pulp exposure and postoperative complications [3-5]. While non-selective removal uses the same assessment criterion everywhere in the cavity (thus leading to possibly harmful removal of dentin in proximity to the pulp), selective removal aims to leave hard dentin in the periphery and soft or leathery dentin in the pulpo-proximal areas of the cavity $[1,2]$. Stepwise removal stands in-between, with the first step equaling selective removal, followed by a temporary sealing of the cavity, followed by re-opening some months later and non-selective removal [1]. While both stepwise and selective removal are recommended for treating deep lesions in permanent teeth, selective removal has some advantages over stepwise removal (i.e., a reduced risk of pulp exposure, fewer number of visits needed, and lower costs) [1, 2].

A number of survey studies, however, indicate that dentists have not widely adopted these less invasive, evidencebased strategies for managing deep lesions [6-9]. So far, it is unknown what the overall proportion of dentists who adopted less invasive carious tissue removal in different countries is and if this proportion has changed with time. Furthermore, it is unknown why dentists adopt or reject selective or stepwise carious tissue and what factors generally drive their decision-making towards deep lesions.

The objective of this systematic review was to analyze the proportion of dentists surveyed in different countries who employ selective (SE) or stepwise (SW) excavation of deep lesions in permanent teeth and to assess a possible change of this proportion with time. A further objective was to identify barriers and facilitators to adoption of SE/SW instead of non-selective excavation, which could assist tailoring implementation interventions. To reduce the risk of bias during the review process and yield more comprehensive, valid, and reliable results, a theory-based systematic assessment of barriers and facilitators was to be used [10].

\section{Methods}

This review was registered a priori at PROSPERO (CRD42016038047) and was planned to utilize qualitative and quantitative data. However, the included studies were all quantitative (survey or poll design) and did not employ qualitative research. Consequently, and in deviation of the protocol, we used a different scale for risk of bias assessment. The reporting of this study is in accordance with Additional file 1, the PRISMA, and the ENTREQ statement guidelines [11, 12].

\section{Eligibility criteria}

This systematic review included studies that were original and reported on the proportion of dentists utilizing one or the other carious tissue removal strategy and/or reported on barriers or facilitators of such utilization in adults or children with permanent, vital (sensible) teeth with deep carious lesions. No restriction as to the pulp symptomatology was defined a priori, but given the focus of our review only studies investigating the management of teeth where maintaining pulp vitality was an option were included. Studies investigating only the management of the exposed pulp were excluded, as were those investigating management of primary teeth only.

Included studies could be interviews, focus groups, surveys or studies using other observational designs, also if nested in a larger trial with different purpose. Only peerreviewed publications were considered. No language, time, or quality restrictions were applied.

\section{Outcomes}

The outcome of this review was the utilization SE/SW instead of non-selective carious tissue removal. We assessed the proportion of dentists choosing one or both of these removal strategies for deep lesions as well as barriers or facilitators for such utilization.

\section{Information sources \\ Electronic searches}

We searched Embase, Medline via PubMed, Cochrane CENTRAL, PsycINFO, and Google Scholar. We have not searched conference abstracts, as we assumed the information presented there to be too limited to allow synthesis. Dissertation and theses were searched via ProQuest and Dissertations and Theses. We additionally searched for reviews using the Database of Abstracts of Reviews of Effects (DARE), the Health Technology Assessment database (HTA), and NHS EED, as such reviews could have yielder further, so far not identified original studies. In addition, reference lists of identified full texts were screened and cross-referenced. We contacted study authors if required to obtain full texts or for clarification.

\section{Search strategy}

The developed search strategy was as sensitive as possible given the expected limited indexing. The following strategy was used and individualized for each database: Search $((((($ dentists $)$ OR dentist) OR practitioner) OR 
practitioners)) AND (((deep) OR pulp) OR vital)) AND ((((caries) OR carious) OR cavity) OR lesion) OR decay).

\section{Study records Selection process}

A spreadsheet was used for data extraction and management. Both reviewers independently screened titles and compared findings. There was no disagreement. Full texts were assessed independently. No duplicative studies were assessed. Studies were included in agreement.

\section{Data collection process}

Data extraction was performed independently by both reviewers. There were no disagreements during extraction.

\section{Data items}

The following items were collected: authors; year; study type and sampling and survey/interview method; characteristics of dentists being investigated (country and demographics); lesion scenarios; proportion of dentists using different removal strategies; knowledge, attitudes, and believes underlying dentists' decision, as identified by the study itself, or as discussed by the study authors (see below).

\section{Data synthesis}

\section{Data synthesis}

The meta-analysis of the proportion of dentists performing SE/SW per all surveyed dentists was performed using Comprehensive Meta-Analysis 2.2.064 (Biostat, NJ, USA). Heterogeneity was assessed using Cochrane's $Q$ and $I^{2}$-statistics [13]. Since heterogeneity was found high, a random-effect model was used. To explore temporal changes of the proportion, we performed metaregression using the unrestricted maximum-likelihood method $[14,15]$. Publication bias was assessed using funnel plots as well as Egger's regression intercept test [16].

To synthesize qualitative data, we had planned thematic analysis of reported original qualitative data. Given that no qualitative study was included, we relied on reports as to how patient- or dentist-center factors (age, gender, caries risk, practice setting) impacted on decision-making towards deep lesions. We additionally screened the discussion of each manuscript for potentially relevant aspects; findings based on the study authors' judgement were extracted and highlighted as such during the thematic analysis.

Factors possibly associated with dentists' excavation behavior were independently abstracted by both authors. In an iterative approach of theme and category development, relationships between themes and concepts were independently identified by both reviewers [17]. Afterwards, reviewers compared their findings and jointly grouped and translated them into the domains and constructs of the TDF $[18,19]$. The rationale for assignment of the barriers and facilitators to the TDF domains can be found in the Appendix (Additional file 2: Table S1). To improve the applicability of our findings for implementation, TDF domains were aligned with domains of the Behavior Change Wheel to facilitate the deduction of interventions [20]. The developed framework was double-checked by repeated coding and referencing from and to all included studies. Themes and concepts were further classified as barriers (-) or facilitators $(+)$ of selective or stepwise excavation, or as conflicting, i.e., uncertain as to their effect on the target behavior (?) [18, 21, 22].

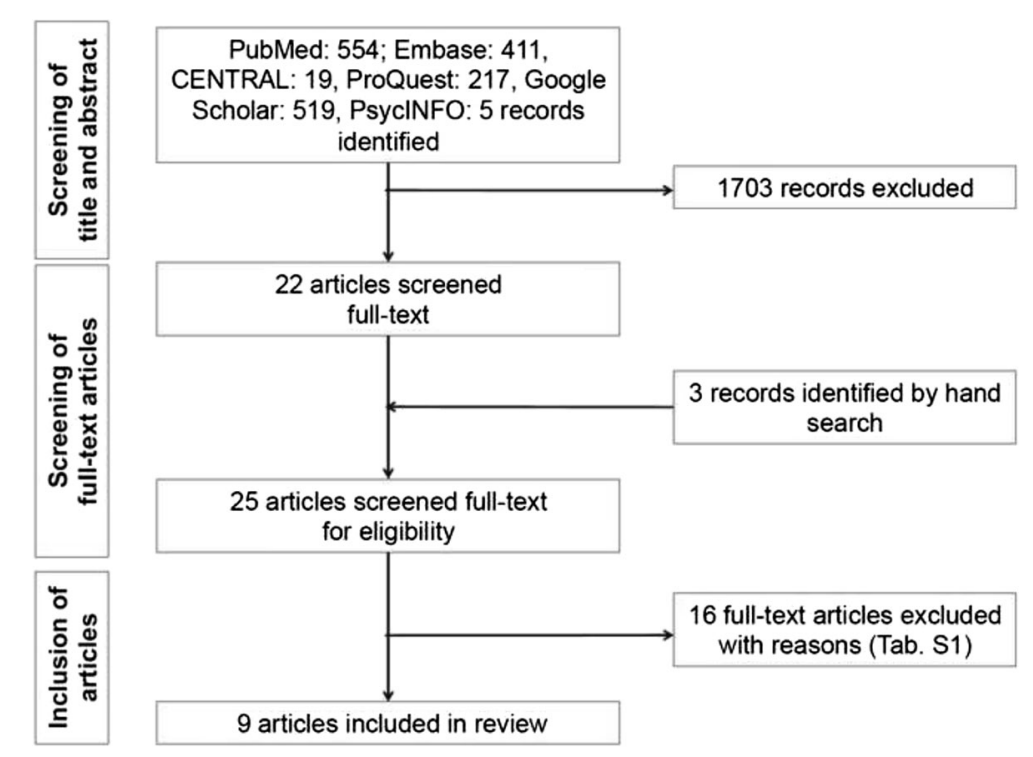

Fig. 1 Flow of the search 
Table 1 Included studies

\begin{tabular}{|c|c|c|c|c|}
\hline Study & Method & $\begin{array}{l}\text { Country, } \\
\text { year }\end{array}$ & Sample & Scenario \\
\hline Oen [9] & Quest & USA, 2006 & $\begin{array}{l}\text { PEARL research } \\
\text { network, response } \\
92 \% \text {, final } 85\end{array}$ & $\begin{array}{l}\text { Deep dentin lesion in } \\
\text { permanent molar with } \\
\text { vital (sensible) pulp } \\
\text { (pain lasts < } 3 \text { s) and } \\
\text { different risk of } \\
\text { exposure }\end{array}$ \\
\hline
\end{tabular}

\begin{tabular}{|c|c|c|c|}
\hline $\begin{array}{l}\text { Seale and } \\
\text { Glickman } \\
{[29]}\end{array}$ & $\begin{array}{l}\text { Real-time USA, } 2007 \\
\text { poll }\end{array}$ & $\begin{array}{l}\text { Conference, } 376 \\
\text { dentists (102 } \\
\text { endodontists, } 252 \\
\text { pedodontists, } 22 \\
\text { others), unclear } \\
\text { response }\end{array}$ & $\begin{array}{l}\text { Young permanent } \\
\text { teeth with open apex }\end{array}$ \\
\hline
\end{tabular}

\begin{tabular}{|c|c|c|c|c|}
\hline Weber [8] & Quest & Brazil, 2009 & $\begin{array}{l}\text { Dentists from one } \\
\text { southern city } \\
44 \% \text { response, } \\
\text { final } 54\end{array}$ & $\begin{array}{l}\text { Deep carious lesion in } \\
\text { permanent molar with } \\
\text { vital pulp and no } \\
\text { spontaneous pain, but } \\
\text { pain when chewing or } \\
\text { cold }\end{array}$ \\
\hline Chisini [34] & Quest & Brazil, 2009 & $\begin{array}{l}\text { Single city, all } \\
\text { dentists, } 68 \% \\
\text { response, final } \\
187\end{array}$ & $\begin{array}{l}\text { Deep lesion in proximity } \\
\text { of pulp, unclear pulp } \\
\text { status and dentition } \\
\text { (assumed permanent) }\end{array}$ \\
\hline
\end{tabular}

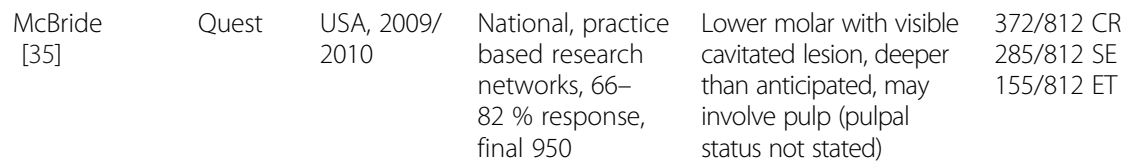

$\begin{array}{ll}\text { Stangvaltaite [7] Quest } & \text { Norway, } \\ 2011\end{array}$

$2011 \quad$ Northern Norway, all dentists, $56 \%$ response, final 222

\begin{tabular}{|c|c|c|c|c|}
\hline Katz [27] & Quest & Brazil, 2012 & $\begin{array}{l}\text { Northeastern } \\
\text { Brazil, participants } \\
\text { of a regional } \\
\text { dentistry } \\
\text { congress, final } \\
123\end{array}$ & Unclear scenario \\
\hline $\begin{array}{l}\text { Schwendicke } \\
\text { [28] }\end{array}$ & Quest & $\begin{array}{l}\text { Germany, } \\
2012\end{array}$ & $\begin{array}{l}\text { Northern } \\
\text { Germany, all } \\
\text { practitioners, } \\
35 \% \text { response, } \\
\text { final } 821\end{array}$ & $\begin{array}{l}\text { Young female patient } \\
\text { with deep lesion in } \\
\text { vital asymptomatic } \\
\text { tooth, risk of pulp } \\
\text { exposure }\end{array}$ \\
\hline
\end{tabular}

Treatment decisions Reasons, barriers, facilitators

No risk of exposure: Age and general caries risk

58/85 CR, 19/85 SE, 8/85 experience of patient influenced endodontic treatment decisions (more invasive in older Risk of exposure: 51/85 and high-risk patients); dentists $\mathrm{CR}, 15 / 85 \mathrm{SE}, 17 / 85 \quad$ knew risk of failure of direct endodontic treatment capping. Authors discuss peer pressure and educational background.

Pedodontists: 179/252 Reasons against SW: second visit SW, endodontists: needed-compliance problems, 222/376 SW MTA pulpotomy better evidence, SE better evidence, reimbursement. Reasons for SW: option to recall symptoms/vitality, root maturation, low costs, re-assess dentin, payment for second appointment.

42/53 CR, 7/53 SW, 4/53 SE/SW: female OR 0.6 (0.2-1.2), SE. We excluded the third case as the pulp and peri-apical status were unclear. younger (graduation >2000): OR 5.5 (1.5-19.7), possible reasons: SW requires second appointment, patients, do not return, younger dentists use evidence-base better.

65/171 CR, 106/171 SE Dentists with more recent graduation or postgraduate training chose SE more often. Authors evaluated experience and setting (public versus private practice versus university).

Age was found a factor, with dentists practicing $5-15$ years performing ET more often, while those $<5$ years performed SE more often; full network participant also more likely to perform SE.

Without symptoms and CR versus SE: male OR 1.5 (0.8-2.8), exposure: 104/212 CR, from Norway: 0.5 (0.2-0.9), public 95/212 SW, $13 / 212$ SE practice: $0.6(0.3-1.3)$, experienced (5+ years): 1.3 (0.7-2.6), urban: 2.2 (1.2-4.1), main reasons for choosing a strategy were good results, easy, restoration longevity, patients' health; SW recommended in guidelines.

59/108 CR, 49/108 SE Majority of dentists considers caries to be treated only restoratively. Attitudes towards minimally invasive dentistry procedures significantly associated with SE (professionals considering minimal invasive as permanent recommended SE); Lack of belief in SE rather than knowledge or specialist status drove decisionmaking.

400/799 CR, 160/799 SE, 239/799 both

Dentists aware of risks and success rates; dentists who accepted bacteria to remain and possible restorative risks were more likely to SE, those who strived for restorative longevity and feared bacteria to remain performed CR and accepted ET. Demographics not a factor; 
Table 1 Included studies (Continued)

\begin{tabular}{|c|c|c|c|c|c|c|}
\hline & & & & & & $\begin{array}{l}\text { generally more or less invasive } \\
\text { dentist types. }\end{array}$ \\
\hline $\begin{array}{l}\text { Schwendicke } \\
\text { [6] }\end{array}$ & Quest & $\begin{array}{l}\text { Germany, } \\
\text { France, } \\
\text { Norway } \\
2015\end{array}$ & $\begin{array}{l}\text { National, all } \\
\text { practitioners, } \\
28-50 \% \\
\text { response, } \\
\text { final } 1481\end{array}$ & $\begin{array}{l}\text { Deep lesion in permanent } \\
\text { tooth with a vital painless } \\
\text { pulp with risk of exposure } \\
\text { in young patient }\end{array}$ & $\begin{array}{l}\text { France: 340/661 CR, } \\
\text { 62/661 SE, 259/661 SW, } \\
\text { Germany: 201/622 CR, } \\
\text { 122/622 SE, 299/622 } \\
\text { SW, Norway: 3/199 CR, } \\
\text { 29/199 SE, 167/199 SW }\end{array}$ & $\begin{array}{l}\text { Male dentists chose SE more often } \\
\text { (OR: } 1.73[1.26 / 2.45]) \text {, dentists in private } \\
\text { setting performed fewer SW (0.60 } \\
[0.39 / 0.93]) \text {, those who believed } \\
\text { bacteria needed removal to avoid } \\
\text { progression chose SE less often } \\
\text { (0.48 [0.33/0.71]), as did those who } \\
\text { feared bacteria to harm the pulp } \\
\text { (0.42 [0.28/0.62]) and vice versa for } \\
\text { those who thought sealed lesions } \\
\text { to arrest (2.84 [1.86/4.36]) or who } \\
\text { strived to avoid exposure (2.18 } \\
[1.40 / 3.29]) \text {. Satisfaction with a } \\
\text { treatment, familiarity and its } \\
\text { evidence-base were main reasons, } \\
\text { only few stated financial issues or } \\
\text { peers as problems, knowledge } \\
\text { also minor factor. Authors discuss } \\
\text { education, caries philosophy as } \\
\text { further reasons. }\end{array}$ \\
\hline
\end{tabular}

The proportion of dentists performing selective (SE), stepwise (SW), "complete" removal (CR), or immediate endodontic treatment (ET) for different scenarios of deep lesions were assessed. In addition, reasons (barriers, facilitators) for the decisions were recorded

\section{Quality assessment and confidence in data}

Quality assessment of included studies was based on the Newcastle-Ottawa Scale (NOS) for cross-sectional studies [23]. Note that we adapted the scale, using an item on questionnaire design, validity and reporting instead of the item on ascertainment of exposure, as the latter was not of relevance in the included studies. We judged studies with $0-3$ of the maximum 8 NOS points ("stars") to have high risk of bias, those with NOS 4-6 moderate and those with NOS 7 or 8 to have low risk of bias. Both reviewers independently assessed the quality of each study. There were no discrepancies during rating.

\section{Results}

\section{Search and included studies}

We identified 554 articles via PubMed, 411 via Embase, 19 via Cochrane CENTRAL, 217 via ProQuest, 519 via Google Scholar, 5 via PsycInfo, and none via DARE or other screened databases. Three more articles were identified via cross-referencing. From these, 25 were screened in full-text and 9 included (Fig. 1). Studies were mainly excluded as they did not investigate the management of deep carious lesions in permanent teeth; one study was excluded as insufficient data were reported and authors could not be contacted. Details on excluded studies can be found in the appendix (Additional file 3: Table S2).

The nine included studies (Table 1) were published between 2007 and 2016. Eight studies used questionnaires and one study real-time polling for surveying. Sample sizes ranged between 54 and 1481 responders, with a response rate between 28 and $92 \%$. Overall, 4199 (3845 general, 354 specialized) dentists were involved. Six studies used a scenario comprising a deep carious lesion in a permanent tooth with either asymptomatic (four studies) or unknown (two studies) pulp status. The other three studies did not use a scenario (two studies) or did not clearly describe the scenario (one study). Participants could usually choose between non-selective (complete) and SE (partial, incomplete) caries removal. Six studies additionally allowed to choose between SW or endodontic treatment (direct capping, pulpotomy, root-canal therapy).

\section{Study quality assessment}

Risk of bias of included studies is shown in Table 2. Most of the included studies were found to have yielded representative samples of dentists. This sample, however, had not always been drawn nationally. Not one study reported on a sample size calculation, and most had significant non-response rates, which were not accounted for sufficiently by all but two studies. The validity of the survey was not described or demonstrated by most studies, and in five studies, the survey instrument was not published. Given the design of all studies, outcomes were only selfreported, which impacts on credibility of the findings. Last, statistical evaluation was not accounting for confounders appropriately. Overall risk of bias was high in four studies [8, 9, 27, 29], moderate in four studies [6, 7, 34, 35], and low in one study [28].

\section{Meta-analysis}

All nine studies contributed to meta-analysis (Fig. 2). In five studies, the majority of participants chose SE/ SW for deep lesions. Overall, the mean (95\% CI) proportion of dentists using SE/SW was $53 \%$ (44/62\%). 
Table 2 Risk of bias according to the modified Newcastle-Ottawa Scale for cross-sectional studies [23]

\begin{tabular}{|c|c|c|c|c|c|c|c|c|c|}
\hline Item & Oen [9] & $\begin{array}{l}\text { Seale and } \\
\text { Glickman } \\
2007 \text { [29] }\end{array}$ & Weber [8] & McBride [35] & Stangvaltaite [7] & Schwendicke [28] & Chisini [34] & Schwendicke [6] & Katz [27] \\
\hline \multicolumn{10}{|l|}{ Selection } \\
\hline $\begin{array}{l}\text { Representativeness } \\
\text { of the sample }\end{array}$ & * & & * & * & * & * & * & * & * \\
\hline \multicolumn{10}{|l|}{$\begin{array}{l}\text { Sample size } \\
\text { determination }\end{array}$} \\
\hline Non-responders & & & & * & & $*$ & & & \\
\hline \multicolumn{10}{|l|}{ Validity of survey } \\
\hline $\begin{array}{l}\text { Checked reliability } \\
\text { and internal } \\
\text { consistency } \\
\text { Survey available }\end{array}$ & & & & $* *$ & & $* *$ & * & $* *$ & \\
\hline Comparability & * & - & - & - & * & $*$ & * & * & - \\
\hline \multicolumn{10}{|l|}{ Outcome } \\
\hline $\begin{array}{l}\text { Assessment of the } \\
\text { outcome }\end{array}$ & * & * & * & * & * & * & * & * & * \\
\hline Statistical test & & & $*$ & & * & * & & * & \\
\hline Overall & $* * *$ & * & $* * *$ & $* * * * *$ & $* * * *$ & $* * * * * * *$ & $* * * *$ & $* * * * *$ & $* *$ \\
\hline
\end{tabular}

For each risk of bias domain, one to two stars could be collected, with a total number of eight stars being possible. We classified studies as high risk (1-3 stars), moderate risk (4-6 stars), or low risk (7-8 stars)

This was significantly associated with the year of study conduct (Fig. 3), with an increasing proportion in later studies $(+1.6 \%$ per year $)$. There was no indication for publication bias via statistical or graphical analysis (Fig. 4).

\section{Factors associated with carious tissue removal behavior} Identified barriers or facilitators or conflicting themes were mapped to a number of TDF domains and constructs, mainly on knowledge, social influence, environmental context, beliefs, and reinforcement (Table 3). These covered all aspects of the Behavioral Change Wheel domains. We found dentists' age to affect knowledge, with an understanding of the disease caries and the scientific rationale behind different excavation strategies eventually affecting behavior. Guidelines, peers, and the social and professional identity of dentists further were associated with the motivation of utilizing behaviors SE/SW. Environmental incentives, sanctions, or restrictions, mainly of financial but also regulatory character, impacted on decision-making, as did

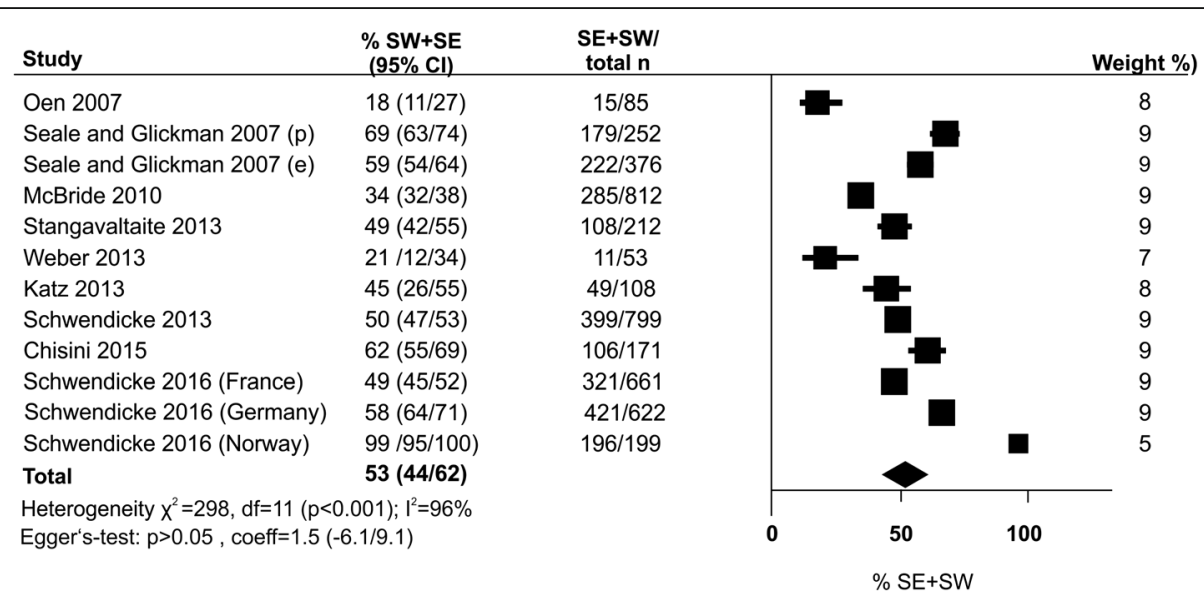

Fig. 2 The proportion of dentists who performed selective (SE) or stepwise (SW) carious tissue removal (\% SW + SW). Wherever possible, subgroups of dentists (according to specialization like pedodontics [p] or endodontics [e], or in different countries) were separately entered into meta-analysis. The pooled proportion and $95 \%$ confidence intervals (bold) from random-effects meta-analysis is shown as diamond. Heterogeneity was assessed using $x^{2}$-test and $P^{2}$-statistics. Publication bias or small-study effects were evaluated using Egger's regression intercept test as well as funnel plot analysis. n total sample size 


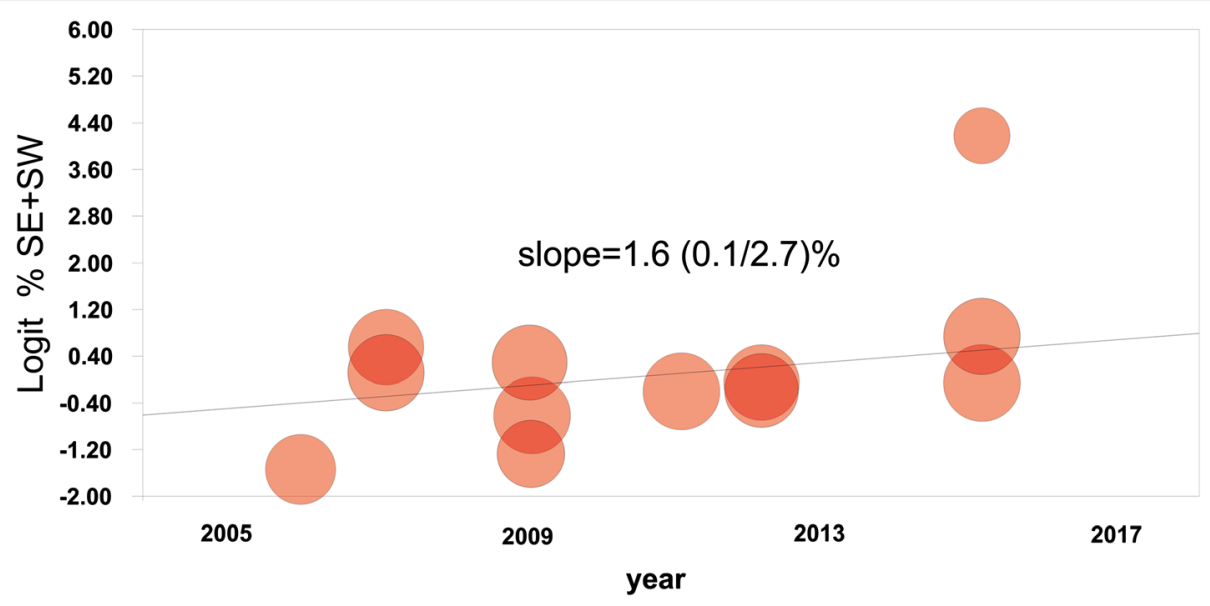

Fig. 3 Association between the year of study publication and the share of dentists performing selective (SE) or stepwise (SW) carious tissue removal. Every circle is the weighted estimate of each study. The regression line indicates a significantly increased share in recent years $(p=0.048)$, with a mean $(95 \% \mathrm{Cl})$ slope of $1.6(0.1 / 2.7 \%)$, i.e., the share increased with $1.6 \%$ per year in mean

the specific indication (the patient, the tooth) and the beliefs on how well different treatments perform. It should be noted that this outcome expectancy was not always related with the chosen excavation strategy. The possible interactions between different domains of the Behavioral Change Wheel (namely, capability, opportunity, and motivation) are summarized in Fig. 5.

\section{Discussion}

This review did not identify qualitative studies on dentists' decision-making with regards to deep carious lesions; we only included quantitative observational studies. The reported barriers and facilitators for utilizing SE/SW have been extracted from these quantitative studies. It is clear that this was unlikely to yield a saturation of themes and concepts, which calls for the conduct of an in-depth study using for example interviews or focus group discussions to yield a deeper understanding of barriers and facilitators on this topic.

We found dentists to rely heavily on invasive strategies for treating deep lesions in permanent teeth: around half of all surveyed dentists preferred nonselective removal or even immediate endodontic treatment for vital teeth, i.e. those where maintaining pulp vitality is-at least in theory-still possible. Such high proportion of unnecessarily invasive interventions is worrisome, as growing evidence indicates that nonselective excavation or the immediate sacrifice of pulp vitality is likely to reduce the retention time of the tooth, burdening the patient and generating significant treatment costs [24-26]. It was noteworthy that more recent surveys yielded a higher proportion of dentists utilizing SE or SW; however, this trend was only borderline significant (which might have to do more with statistical power than a lacking association)

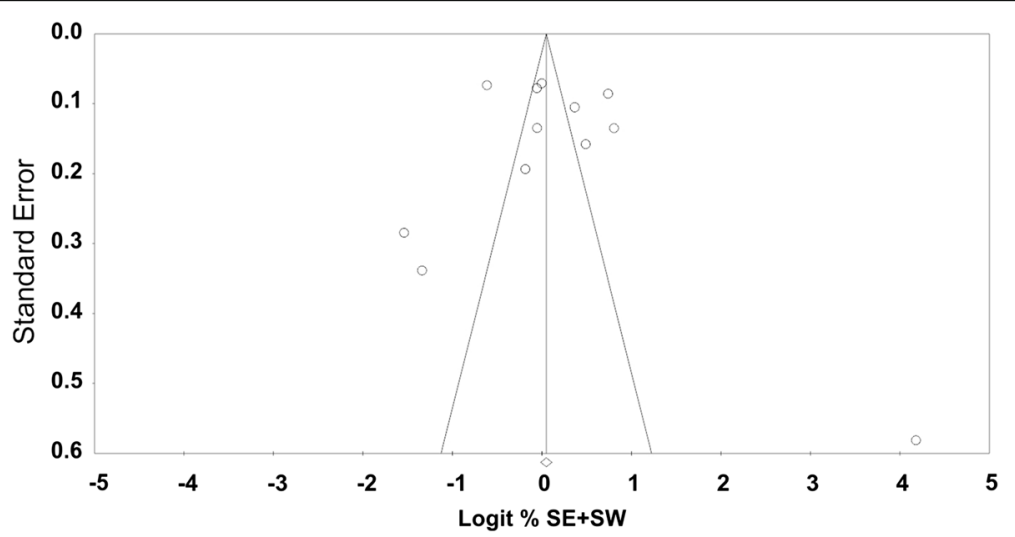

Fig. 4 Funnel plot. Standard errors are plotted against the logarithm of the share of dentists performing selective (SE) or stepwise (SW) carious tissue removal. No significant asymmetry was identified 
Table 3 Mapping of identified themes to COM-B (capability, opportunity, motivation) of the Wheel of Change [36] and TDF domains and constructs [19]

\begin{tabular}{|c|c|c|c|c|c|}
\hline $\begin{array}{l}\text { COM-B } \\
\text { domain }\end{array}$ & TDF domain & TDF construct & $\begin{array}{l}\text { Identified enabler (+) or barrier } \\
(-) \text { or conflicting theme (?) }\end{array}$ & Explanation & Reference \\
\hline \multirow[t]{2}{*}{ Capability } & Knowledge & $\begin{array}{l}\text { Knowledge of } \\
\text { condition, scientific } \\
\text { rationale }\end{array}$ & $\begin{array}{l}(-) \text { age (younger dentists more } \\
\text { likely to perform SE or SW) } \\
\text { (+) understanding of caries } \\
\text { (acceptance of remaining } \\
\text { bacteria being sealed) }\end{array}$ & $\begin{array}{l}\text { Younger dentists have different } \\
\text { knowledge on caries and the } \\
\text { rationale of carious tissue removal. }\end{array}$ & $\begin{array}{l}{[6-9,27-29,34,} \\
35]\end{array}$ \\
\hline & Skills & $\begin{array}{l}\text { Procedural knowledge, } \\
\text { skills, competence, } \\
\text { ability }\end{array}$ & $\begin{array}{l}\text { (+) dentists oftentimes adopt } \\
\text { to new techniques (liners, } \\
\text { burs etc.) }\end{array}$ & $\begin{array}{l}\text { Many dentists are adopters of } \\
\text { technical change; skills are not a } \\
\text { barrier for different carious } \\
\text { tissue removal. }\end{array}$ & {$[6-9,27,29,34]$} \\
\hline \multirow[t]{3}{*}{ Opportunity } & Social influence & $\begin{array}{l}\text { Social pressure, norms, } \\
\text { support, modelling }\end{array}$ & $\begin{array}{l}(-) \text { peers } \\
(+) \text { being part of a practice } \\
\text { network }\end{array}$ & $\begin{array}{l}\text { Fears of peers not accepting SE or } \\
\text { SW are barriers. A practice network } \\
\text { drives a different group dynamics } \\
\text { and facilitates change. }\end{array}$ & {$[6,9,35]$} \\
\hline & Social role & $\begin{array}{l}\text { Professional identity, } \\
\text { confidence }\end{array}$ & $\begin{array}{l}\text { (?) gender (most studies found } \\
\text { female dentists choosing SE or } \\
\text { SW more often) }\end{array}$ & $\begin{array}{l}\text { Male dentists might have different } \\
\text { professional identity which could } \\
\text { act as barrier. }\end{array}$ & {$[6,7,29]$} \\
\hline & $\begin{array}{l}\text { Environmental } \\
\text { context and } \\
\text { resources }\end{array}$ & $\begin{array}{l}\text { Stressors, resources, } \\
\text { organizational culture }\end{array}$ & $\begin{array}{l}\text { (-) financial aspects, private } \\
\text { practice model associated with } \\
\text { more invasive treatments } \\
\text { (+) presence of guidelines } \\
\text { (e.g. for stepwise in Norway) } \\
\text { (?) healthcare organization } \\
\text { (significant between-country } \\
\text { differences) }\end{array}$ & $\begin{array}{l}\text { Being paid for quantities of } \\
\text { treatment sets the incentive to } \\
\text { treat, not to maintain pulp vitality. } \\
\text { Such incentive was especially found in } \\
\text { private practices (fee for item } \\
\text { reimbursement). Reimbursement } \\
\text { and regulation in different countries } \\
\text { could lead to observed between- } \\
\text { country differences. Having } \\
\text { guidelines towards less invasive } \\
\text { excavation facilitates change. }\end{array}$ & {$[6,7,28,29]$} \\
\hline \multirow[t]{5}{*}{ Motivation } & $\begin{array}{l}\text { Beliefs about } \\
\text { capabilities }\end{array}$ & $\begin{array}{l}\text { Self-confidence, } \\
\text { competence, control }\end{array}$ & $\begin{array}{l}\text { (-) education, role of the } \\
\text { dentists as perceived as } \\
\text { expert }\end{array}$ & $\begin{array}{l}\text { Dentists see themselves as experts. } \\
\text { The acquired education is a firm } \\
\text { foundation for their beliefs, which } \\
\text { could act as barrier. }\end{array}$ & {$[7,29,34]$} \\
\hline & $\begin{array}{l}\text { Beliefs about } \\
\text { consequences }\end{array}$ & $\begin{array}{l}\text { Outcome } \\
\text { expectancies }\end{array}$ & $\begin{array}{l}\text { (?) knowledge on expected } \\
\text { outcomes } \\
\text { (?) patient or tooth specific } \\
\text { expectations } \\
\text { (-) compliance needed in SW }\end{array}$ & $\begin{array}{l}\text { The expected outcome might } \\
\text { drive some decisions (decisions } \\
\text { are tailored to teeth or patients } \\
\text { based on different expectations). } \\
\text { However, expectations are not } \\
\text { always predicting decisions. }\end{array}$ & {$[8,9,27-29,34]$} \\
\hline & Reinforcement & Rewards, incentives & $\begin{array}{l}\text { (-) financial aspects, practice } \\
\text { settings }\end{array}$ & See above. & {$[7,28,29,34]$} \\
\hline & & Sanctions, punishment & $\begin{array}{l}\text { (-) healthcare organization } \\
\text { (country-specific, guarantee } \\
\text { times for restorative) }\end{array}$ & See above. & {$[6,28,29]$} \\
\hline & $\begin{array}{l}\text { Memory attention } \\
\text { and decision } \\
\text { process, } \\
\text { optimism }\end{array}$ & $\begin{array}{l}\text { Decision process, } \\
\text { pessimism }\end{array}$ & (-) compliance needed in SW & See above. & {$[7,8,29]$} \\
\hline
\end{tabular}

and could be an artifact given that dentists in different countries were surveyed. However, data from Germany confirmed this trend, where a representative sample of dentists from Northern Germany had been surveyed in 2013, with $49 \%$ considering SE/SW [28], while this number increased to $68 \%$ in a national sample in 2016 [6].

Using thematic analysis and mapping the identified themes to constructs of the TDF allowed us to understand a number of aspects which were associated with dentists' decision-making for deep lesions. One relevant domain was knowledge; however, several studies found that knowledge on expected outcomes (success rates of different strategies) did not necessarily predict decision-making [27-29]. Instead, an understanding of the disease caries and the associated scientific rationale behind different excavation strategies seemed more important: dentists who understood caries as infectious disease and who feared remaining bacteria to harm the pulp preferred non-selective excavation more frequently. 


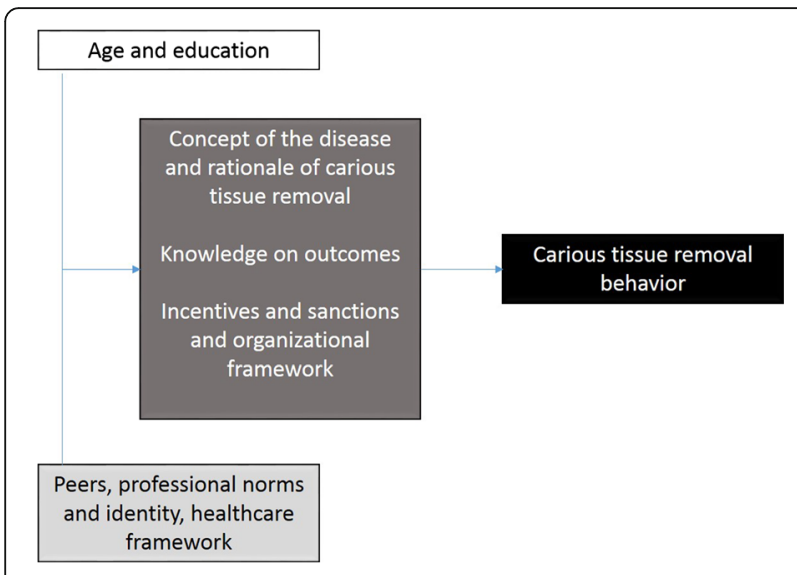

Fig. 5 Identified factors shaping dentists' carious tissue removal behavior according to the domains of the Behavior Change Wheel [20]. Capability (white box) is shaped by dentists' education, which in turn differs between younger and older dentists. Opportunity (light grey box) is influenced by peers and associated professional norms and identities as well as healthcare organization. Both capability and opportunity shape dentists' motivation (dark grey box), which is affected by the understanding of the disease caries and the rationale of carious tissue removal, knowledge on the outcomes (of different removal strategies, but also endodontic therapies), and healthcare incentives or sanctions. All factors eventually guide the carious tissue removal behavior (black box)

It was further assuring to find younger dentists to be less invasive than older dentists in most studies; something which we ascribe to a change in education concepts. Future studies should engage into understanding the impact of gender, as most but not all studies found male dentists to be more invasive than female dentists.

A second factor was the context of the decision: Specific patient or tooth level aspects (patient's age, tooth maturity, type of exposure) seemed to guide decision-making, again something which is likely to relate to knowledge, and could be tackled by future implementation interventions. The presence (or absence) of professional guidelines was stated as one facilitator (or barrier) for performing SE/SW. The opinion of peers towards different removal strategies seems to impact (with presumably different peer pressure in practice research networks, for example). Healthcare regulations and incentives or sanctions (financial gain from different treatments, sanctions on restorative complications) were further aspects.

This study has a number of strengths and limitations. First and as discussed, our qualitative findings are relatively limited and unlikely to represent all relevant themes. The use of a theoretical base for understanding these aspects, however, strengthens the credibility of our findings, as the TDF is a comprehensive and validated instrument. The constructed link to the Behavior Change Wheel further supports the use of our data for studies on implementation interventions. Second, we needed to make some assumptions for assigning barriers or facilitators to the TDF domains. For example, we assumed that a specific "education of the dentist" might act as a barrier when considering it from the TDF domain "self-confidence, competence, and control." That was done, as we assumed that dentists, confidently perceiving themselves as the main experts on caries treatment, might be reluctant to adopt changes to their daily practice. This assumption (and others) might be disputable; this uncertainty when assigning themes to TDF domains should be born in mind when interpreting our findings. Third, the quantitative aspects of our study are built on a limited number of studies; this limited number might be the result of the applied inclusion criteria. In this sense, we could have considered conference abstracts for inclusion, and could have contacted abstract authors for more detailed information. The included studies were additionally very heterogeneous. For example, sample sizes, sampling methods, survey instruments, and constructed scenarios differed widely, which probably contributed to the observed statistical heterogeneity. That was also the reason why we did not attempt to pool data on barriers and facilitators, which were additionally scarce. Moreover, only six countries were assessed in total (some several times), which prohibits generalization of our findings. The included studies were all surveys or polls by design, i.e., yielded self-reported data, and had further qualitative weaknesses (mainly related to sampling, non-response, and the used instrument). The associated risk of bias is likely to lead to some distortions (via the Hawthorne effect or selection bias, for example). Last, we only assessed decision-making in permanent teeth, while a number of studies investigated dentists' behavior in primary teeth $[30,31]$. Given the clinical decisions to be made and their consequences being very different in primary versus permanent teeth, we had decided to not include studies on primary teeth.

A number of recommendations can be deduced from this study. Future research in this direction should involve qualitative elements to yield a deeper understanding of barriers and facilitators of utilizing SE/SW. When using a less rigid format than a predefined survey, new themes and concepts are likely to emerge. Possible interventions on increasing the proportion of dentists performing SE/SW instead of nonselective excavation should focus on improving the understanding of the disease caries and the rationale behind different excavation strategies [32, 33] and should aim to eliminate barriers for evidence-based management of deep lesions on both practice and healthcare level. 


\section{Conclusions}

Nearly half of all dentists sampled by the included studies preferred invasive instead of evidence-based management strategies for deep carious lesions in permanent teeth. In recent years, this proportion seems to decrease. Dentists' behavior was affected by a range of factors, from their understanding of what constitutes caries and how it should be managed in general, over contextual factors to systemic (oftentimes economic) reinforcement mechanisms. Given only quantitative studies being included in this review, future studies should involve some qualitative elements to yield a deeper understanding of barriers and facilitators towards less invasive carious tissue removal. Such understanding would also be needed for tailoring implementation of interventions.

\section{Additional files}

Additional file 1: PRISMA 2009 checklist. (DOC 63 kb)

Additional file 2: Table S1. Rationale for assignment of different identified enabler (+), barrier (-), or conflicting (?) themes to the TDF domains. (DOC $34 \mathrm{~kb}$ )

Additional file 3: Table S2. Excluded studies. (DOC 76 kb)

\section{Abbreviations}

COM-B: Capability, opportunity, motivation and behavior model; CR: Complete removal of caries; ET: Endodontic treatment; NOS: Newcastle-Ottawa Scale; SE: Selective excavation; SW: Stepwise excavation; TDF: Theoretical domains framework

\section{Funding}

FS receives a grant from the German Research Foundation (SCHW 1766/2-1).

Availability of data and materials

All data are available in this manuscript.

\section{Authors' contributions}

FS and GG developed the study, the search strategy, the selection criteria, the risk of bias assessment strategy, and data extraction criteria. FS provided statistical expertise and clinical expertise. FS and GG read, provided the feedback, and approved the final manuscript.

\section{Competing interests}

The authors declare that they have no competing interests.

\section{Consent for publication}

Not applicable.

\section{Ethics approval and consent to participate}

Not applicable.

Received: 15 June 2016 Accepted: 7 October 2016

Published online: 19 October 2016

\section{References}

1. Marcenes W, Kassebaum NJ, Bernabé E, Flaxman A, Naghavi M, Lopez A Murray CJL. Global burden of oral conditions in 1990-2010: a systematic analysis. J Dent Res. 2013;92:592-7.

2. Listl S, Galloway J, Mossey PA, Marcenes W. Global economic impact of dental diseases. J Dent Res. 2015.

3. Schwendicke F, Frencken JE, Bjorndal L, Maltz M, Manton DJ, Ricketts D, Van Landuyt K, Banerjee A, Campus G, Domejean S, et al. Managing carious lesions: consensus recommendations on carious tissue removal. Adv Dent Res. 2016;28:58-67.
4. Schwendicke F, Dorfer CE, Paris S. Incomplete caries removal: a systematic review and meta-analysis. J Dent Res. 2013;92:306-14.

5. Ricketts D, Lamont T, Innes NP, Kidd E, Clarkson JE. Operative caries management in adults and children. Cochrane Database Syst Rev. 2013;28, CD003808.

6. Schwendicke F, Stangvaltaite L, Holmgren C, Maltz M, Finet M, Elhennawy K, Eriksen I, Kuzmiszyn TC, Kerosuo E, Domejean S. Dentists' attitudes and behaviour regarding deep carious lesion management: a multi-national survey. Clin Oral Investig. 2016.

7. Stangvaltaite $L$, Kundzina R, Eriksen HM, Kerosuo E. Treatment preferences of deep carious lesions in mature teeth: questionnaire study among dentists in northern Norway. Acta Odontol Scand. 2013;71:1532-7.

8. Weber CM, Alves LS, Maltz M. Treatment decisions for deep carious lesions in the public health service in southern Brazil. J Public Health Dent. 2011;71:265-70.

9. Oen KT, Thompson VP, Vena D, Caufield PW, Curro F, Dasanayake A, Ship JA, Lindblad A. Attitudes and expectations of treating deep caries: a PEARL network survey. Gen Dent. 2007;55:197-203.

10. Green J. The role of theory in evidence-based health promotion practice. Health Educ Res. 2000;15:125-9.

11. Tong A, Flemming K, Mclnnes E, Oliver S, Craig J. Enhancing transparency in reporting the synthesis of qualitative research: ENTREQ. BMC Med Res Methodol. 2012;12.

12. Moher D, Shamseer L, Clarke M, Ghersi D, Liberati A, Petticrew M. Preferred Reporting Items for Systematic Review and Meta-Analysis Protocols (PRISMA-P) 2015 statement. Syst Rev. 2015;4.

13. Higgins JPT, Thompson SG. Quantifying heterogeneity in a meta-analysis. Stat Med. 2002;21:1539-58.

14. Higgins JPT, Green S. Cochrane Handbook for Systematic Reviews of Interventions. Version 5.10 (updated March 2011): The Cochrane Collaboration; 2011. http:// handbook.cochrane.org.

15. Altman DG, Bland JM. Interaction revisited: the difference between two estimates. BMJ. 2003;326:219.

16. Egger M, Smith GD, Schneider M, Minder C. Bias in meta-analysis detected by a simple, graphical test. BMJ. 1997;315:629-34.

17. Jensen LA, Allen MN. Meta-synthesis of qualitative findings. Qual Health Res. 1996;6

18. Noblit GW, Hare RD. Meta-ethnography: synthesizing qualitative studies. Newbury Park: Sage; 1988.

19. Cane J, O'Connor D, Michie S. Validation of the theoretical domains framework for use in behaviour change and implementation research. Implement Sci. 2012;7:1-17.

20. Michie S, van Stralen MM, West R. The behaviour change wheel: a new method for characterising and designing behaviour change interventions. Implement Sci. 2011;6:42.

21. Lau R, Stevenson F, Ong BN, Dziedzic K, Treweek S, Eldridge S, Everitt $H$, Kennedy A, Qureshi N, Rogers A, et al. Achieving change in primary care-causes of the evidence to practice gap: systematic reviews of reviews. Implement Sci. 2016;11:1-39.

22. Walsh D, Downe S. Meta-synthesis method for qualitative research: a literature review. J Adv Nurs. 2005:50.

23. Wells G, Shea B, O'Connell D, Peterson J, Welch V, Losos M, Tugwell P. The Newcastle-Ottawa Scale (NOS) for assessing the quality of nonrandomised studies in meta-analyses. 2009. http://www.ohri.ca/programs/clinical_ epidemiology/oxford.asp.

24. Schwendicke F, Paris S, Tu YK. Effects of using different criteria for caries removal: a systematic review and network meta-analysis. J Dent. 2015:43:1-15.

25. Schwendicke F, Stolpe M. Direct pulp capping after a carious exposure versus root canal treatment: a cost-effectiveness analysis. J Endod. 2014;40:1764-70.

26. Schwendicke F, Stolpe M, Meyer-Lückel H, Paris S, Dörfer C. Costeffectiveness of one- and two-step incomplete and complete excavation. J Dent Res. 2013;92:880-7.

27. Katz CR, de Andrade MR, Lira SS, Ramos Vieira EL, Heimer MV. The concepts of minimally invasive dentistry and its impact on clinical practice: a survey with a group of Brazilian professionals. Int Dent J. 2013;63:85-90.

28. Schwendicke F, Meyer-Lueckel H, Dorfer C, Paris S. Attitudes and behaviour regarding deep dentin caries removal: a survey among German dentists. Caries Res. 2013:47:566-73.

29. Seale NS, Glickman GN. Contemporary perspectives on vital pulp therapy: views from the endodontists and pediatric dentists. J Endod. 2008;34:S57-61.

30. Fukai $\mathrm{K}$, Ohno H, Blinkhorn A. A cross-sectional survey investigating care of the primary dentition by paediatric dental specialists in Japan and the UK. Int Dent J. 2012;62:203-7. 
31. Inglehart MR, Peters MC, Flamenbaum MH, Eboda NN, Feigal RJ. Chemomechanical caries removal in children: an operator's and pediatric patients' responses. J Am Dent Assoc. 2007;138:47-55.

32. Schulte A, Pitts N, Huysmans M, Splieth C, Buchalla W. European core curriculum in cariology for undergraduate dental students. Eur J Dent Educ. 2011;15:9-17.

33. Splieth C, Innes N, Sohnel A. Evidence-based cariology in clinical and public health practice as part of the European core curriculum in cariology. Eur J Dent Educ. 2011;15:45-51.

34. Chisini LA, Conde MC, Correa MB, Dantas RV, Silva AF, Pappen FG, Demarco FF. Vital pulp therapies in clinical practice: findings from a survey with dentist in southern Brazil. Braz Dent J. 2015;26:566-71.

35. McBride R, Leroux B, Lindblad A, Williams OD, Lehmann M, Rindal DB, Botello-Harbaum M, Gilbert GH, Gillette J, Demko C. Measuring the impact of practice-based research networks on member dentists in the Collaboration on Networked Dental and Oral Health Research, CONDOR. J Dent. 2013:41:393-403.

36. Michie S, van Stralen M, West R. The Behaviour Change Wheel: a new method for characterising and designing behaviour change interventions. Implement Sci. 2011;6.

Submit your next manuscript to BioMed Central and we will help you at every step:

- We accept pre-submission inquiries

- Our selector tool helps you to find the most relevant journal

- We provide round the clock customer support

- Convenient online submission

- Thorough peer review

- Inclusion in PubMed and all major indexing services

- Maximum visibility for your research

Submit your manuscript at www.biomedcentral.com/submit
Biomed Central 